\title{
Uma história de historiadores ausentes? Um chamado à reflexão historiográfica
}

\author{
A history of missing historians? \\ A call for historiographical reflection
}

\author{
Gabriel Lopes \\ Pós-doutorando, Programa de Pós-graduação em História das Ciências e da Saúde/Casa de Oswaldo Cruz/Fiocruz. \\ gabriel.lopes.mailbox@gmail.com
}

Letícia Pumar

Pós-doutoranda, Programa de Pós-graduação em História/Universidade Federal Rural do Rio de Janeiro.

leticiapumar@gmail.com

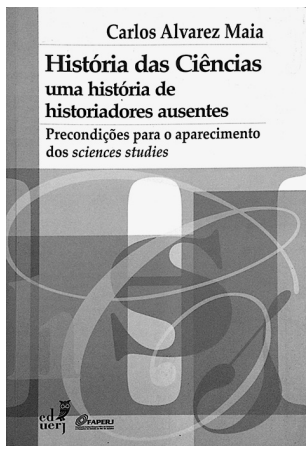

MAIA, Carlos Alvarez. História das ciências: uma história de historiadores ausentes: precondições para o aparecimento dos sciences studies. Rio de Janeiro: Eduerj. 2013. $306 \mathrm{p}$.
O mais belo mito contemporâneo é a ideia de uma ciência depurada de qualquer mito.

(Michel Serres, 1996, p.175)

livro do historiador Carlos Alvarez Maia é motivado por um
questionamento provocativo: seria a história das ciências uma história de historiadores ausentes? Não se trata de uma constatação pessimista, mas sim de um esforço reflexivo que busca mobilizar e tornar os historiadores sensíveis ao problema. Maia aponta que a ausência de uma abordagem mais substancial sobre as ciências na historiografia pode ser historicizada. Quais as possibilidades e os desafios que enfrentamos quando nos propomos a analisar as ciências como práticas culturais historicamente situadas?

O tema desse livro acompanha Maia desde os anos de 1980. Ao se formar em física, em 1978, pela Pontifícia Universidade Católica do Rio de Janeiro, ele possuía tanto a inquietação quanto o ambiente necessário para que seu interesse pela história das ciências levasse a questionamentos que se encontram na base do seu argumento. A influência de Hilton Ferreira Japiassú em sua formação e seu interesse em questões epistemológicas alimentado pela leitura de autores como Thomas Kuhn, Alexandre Koyré e Paul Feyerabend em um grupo de estudos dentro do próprio curso de física organizado por Mário Bunge são elementos importantes para se compreender o caminho trilhado por Maia da física até a historiografia das ciências e sua própria inquietação a respeito da historicidade da 
história das ciências (Silva, Araújo, Silva, 2011, p.12). Maia destaca o problema da resistência dos historiadores em tomar o conteúdo das ciências como objeto de estudo. O conceito central do seu livro é a palavra "historicização". O sentido de historicização para ele não está relacionado apenas à forma de se estudar determinados grupos de cientistas e suas instituições, mas pretende fazer parte da reflexão teórica da própria área de história das ciências. Para entrar no argumento do autor é necessário não apenas compreender a historicização política e institucional das ciências, mas refletir também sobre os problemas enfrentados pelos próprios historiadores em seu ofício, ou seja, para ele, a historiografia que não se ocupa em analisar historicamente os pressupostos científicos também deve ser historicizada. Dessa maneira, a análise é centrada nos "principais eventos historiográficos do século XX situados desde a década de 1920 até 1970 que, sob o manto do cientificismo, alimentaram o afastamento da história das ciências das análises efetivamente histórico-sociais" (p.13). Maia aponta para um "hiato historiográfico", ou seja, um longo período no qual não foram desenvolvidas análises histórico-sociológicas sobre o saber científico nos moldes da sociologia do conhecimento de Karl Mannheim e do livro Gênese e desenvolvimento de um fato científico ([1935] 2010), de Ludwik Fleck, até a chegada dos sciences studies na década de 1970. Para Maia, o período que se estende do final da Primeira Guerra Mundial até o pós-Segunda Guerra foi marcado por um fortalecimento de estudos sobre a atividade científica que partiam de posições próximas à análise epistemológica da "demarcação descoberta-justificação" proposta por Rudolf Carnap e Hans Reichenbach, alimentando a infrutífera querela internalismo-externalismo.

A problemática é instigante e bem formulada, a questão do "hiato historiográfico" parece encorajar historiadores a realizar estudos mais aprofundados. No entanto, por vezes Maia parece recorrer ao sedutor atalho das história das ideias, para chegar à questão que lhe parece central, a importância do pensamento fleckiano para a história das ciências. Fica-nos a impressão de que o livro é um exemplo das grandes dificuldades que encontramos quando nos propomos a analisar o ato de conhecer em uma perspectiva realmente histórica. Assim, Maia desbrava caminhos muito relevantes que devem ser percorridos por novos estudos, mas que só puderam ter sido abertos porque o autor correu riscos, vacilando e apostando a cada novo passo em um terreno ainda pouco explorado por historiadores brasileiros.

Maia corajosamente convoca os historiadores sensíveis aos problemas que levanta para que façam frente ao desafio de se empenhar em uma historicização das ciências mais comprometida com uma abordagem que considere não apenas as práticas sociais científicas, mas também a relação delas com o seu conteúdo. Dessa forma, faz frente às resistências, tanto das disciplinas que são objeto de estudo quanto da própria historiografia que desencoraja uma aproximação a esses objetos e recua frente a desafios teóricos arriscados, que poderiam ser extremamente relevantes aos debates teóricos sobre o próprio ofício do historiador.

O livro é, sobretudo, uma reflexão séria e comprometida com maior permeabilidade entre as humanidades e as ciências da natureza, uma possibilidade de história sem reservas: "o que antevejo para o futuro não é uma disputa acirrada entre 'nativos' e 'estrangeiros'”, aponta Maia (p.20), referindo-se à necessidade de uma perspectiva mais transdisciplinar para enfrentar esse desafio. Para ele, "com o maior desenvolvimento dos science studies, difunde-se cada vez mais nas diversas corporações de ofício - sejam historiadores, sociólogos, antropólogos, 
educadores ou até mesmo cientistas naturais - um olhar que apresenta a atividade científica como uma atividade constituída historicamente".

O livro faz parte de um projeto intelectual que se concretiza em diversos artigos científicos, mas principalmente em sua prática de docência. Em História, ciência e linguagem, livro publicado em 2014, Maia já aponta problemas e limitações dentro dos próprios science studies, especialmente em algumas ideias defendidas por Bruno Latour, e aponta outro caminho, uma via propriamente histórica, inspirada principalmente no pensamento de Ludwik Fleck, utilizando também a ideia de reciprocidade das agências. Dessa forma, não apenas aponta uma ausência de historiadores na história das ciências, mas procura se fazer presente apontando saídas para os desafios historiográficos que levanta em outras publicações.

Maia chama os historiadores brasileiros a refletir sobre a produção de conhecimentos como empreitada coletiva e historicamente situada. A história das ciências não teria a ver apenas com certa "temática" (pesquisas históricas sobre determinadas instituições e personagens do campo científico), mas representaria um exemplo de uma história viva e engajada - feita por intelectuais de diversas formações - que poderia trazer reflexões significativas sobre o ato de produzir conhecimento, sobre o valor que o "científico" tem na nossa sociedade, sobre a própria dinâmica da comunidade de que fazemos parte como pesquisadores/historiadores, ou seja, sobre o nosso presente e sobre o nosso "fazer".

\section{REFERÊNCIAS}

FLECK, Ludwik.

Gênese e desenvolvimento de um fato científico. Tradução Georg Otte, Mariana Camilo de Oliveira. Belo Horizonte: Fabrefactum. 2010.

MAIA, Carlos Alvarez.

História, ciência e linguagem: o dilema do relativismo-realismo. Rio de Janeiro: Mauad X. 2014.

SERRES, Michel.

Diálogos sobre a ciência, a cultura e o tempo: conversas com Bruno Latour. Lisboa: Instituto Piaget. 1996.
SILVA, Emilly Joyce Oliveira Lopes; ARAÚJO, George Fellipe Zeidan Vilela; SILVA, Paloma Porto.

História, verdade e linguagem: a historicidade das ciências: entrevista com o Prof. Dr. Carlos Alvarez Maia. Temporalidades, v.3, n.2, p.12-21. 2011. Disponível em: https://seer.ufmg.br/index. php/temporalidades/article/view/3124. Acesso em: 2 nov. 2016. 